\title{
Effect of irrigation and nitrogen fertilization on the agronomic traits and yield of irrigated rice
}

\author{
Alberto Baêta dos Santos ${ }^{1 *}$, Nand Kumar Fageria ${ }^{1}$, Luís Fernando Stone ${ }^{1}$, Talita Pereira Baêta Santos ${ }^{2}$
}

\author{
$10.1590 / 0034-737 X 201663050018$
}

\begin{abstract}
Water and nitrogen management is essential to achieve high yield potential in irrigated agricultural systems. This study aimed to evaluate the influence of flood timing and nitrogen management on the agronomic performance of irrigated rice in tropical lowland. Two experiments were conducted in a Dystrophic Haplic Gleysol during the 2007/08 and 2008/09 crop years. The experiments were carried out using the cultivars BRS Jaçanã and Epagri 109. Flood timing combined with timing of topdressing $90 \mathrm{~kg} \mathrm{ha}^{-1} \mathrm{~N}$ was evaluated at 15, 30, 45 and 60 days after emergence. The experiment was arranged in a split plot completely randomized design, flood timing in the plots and $\mathrm{N}$ application in the subplots, with six replications. Late flooding as well as late nitrogen application resulted in reduction of phytobiomass, grain quality and yield of irrigated rice. Flooding is recommended at the beginning of tillering for cultivar that shows higher initial growth, while for slower growth cultivar, ponding water can be established until mid-tillering. Early flooding increases sheath blight severity in rice stems. For improved quality and productive potential of irrigated rice, early flooding period and efficient sheath blight control is necessary.
\end{abstract}

Key words: Oryza sativa L.; flooding; nitrogen; yield components; grain quality.

\section{RESUMO}

\section{Irrigação e adubação nitrogenada na produtividade de grãos e nas características agronômicas do arroz irrigado}

Os manejos da água e da adubação nitrogenada estão entre as técnicas necessárias para atingir alto potencial produtivo nos sistemas agrícolas irrigados. Objetivou-se determinar a influência de épocas de início da inundação e de aplicação de $\mathrm{N}$ no desempenho agronômico do arroz irrigado em várzea tropical. Foram conduzidos dois experimentos num Gleissolo Háplico distrófico, nas safras 2007/08 e 2008/09. Em um experimento foi empregado o cultivar BRS Jaçanã e, no outro, o Epagri 109. Avaliaram-se, aos 15, 30, 45 e 60 dias após a emergência, as épocas de início da inundação combinadas com épocas de aplicação de $90 \mathrm{~kg} \mathrm{ha}^{-1} \mathrm{de} \mathrm{N}$ em cobertura. O delineamento experimental foi o inteiramente casualizado, com seis repetições, no esquema de parcelas subdivididas constituídas pelas épocas da inundação e as subparcelas pelas épocas de aplicação do N. Atraso tanto na época de início da inundação contínua como na época de aplicação de nitrogênio acarretam redução na biomassa, na qualidade e na produtividade de grãos de arroz irrigado. Para cultivar que apresenta maior crescimento inicial a inundação deve ocorrer no início do perfilhamento, enquanto que para cultivar de crescimento mais lento a lâmina de água pode ser estabelecida até meado do perfilhamento. A inundação precoce favorece a severidade de queima-da-bainha nos colmos. Para obter o potencial produtivo do arroz irrigado com melhor qualidade é necessário associar a época precoce de submersão do solo com controle eficiente de queima-da-bainha.

Palavras-chave: Oryza sativa L.; inundação; nitrogênio; componentes da produtividade; qualidade de grãos.

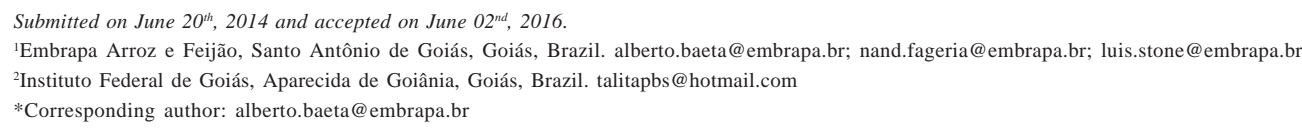




\section{INTRODUCTION}

The appropriate management of irrigation water and the rational use of fertilizers, together with the use of cultivars that are efficient in the absorption and utilization of nutrients, especially nitrogen $(\mathrm{N})$, are some of the technologies used to increase and sustain agricultural production in the long term (Fageria et al., 2008; Fageria et al., 2010). Adequate management of these practices enables sustainable grain yield and quality of production.

The physiological traits of the rice plant, the physical, chemical and biological soil properties and nutrient availability are influenced by the maintenance of the water layer on the soil surface. The water use efficiency of irrigated rice, that is, grain yield per unit of evapotranspiration varies around $1.1 \mathrm{~kg}$ of grain per cubic meter of water, reaching up to $1.6 \mathrm{~kg} \mathrm{~m}^{-3}$, which is comparable to other cereals (Stone, 2005). The low amount of grain produced in relation to the volume of water used in the irrigated rice crop is greatly a result of improper management of irrigation water. Besides the losses by evapotranspiration, water losses also occur in the production system.

Nitrogen availability to plants and its relation to the increase in production components are considered the most influential factors in rice productivity (Fageria \& Stone, 2003; Fageria et al. 2003; Fageria, 2007; Fageria et al., 2013). Nitrogen increases the shoot dry matter, grain harvest index, and $\mathrm{N}$ harvest index, parameters that are positively associated with grain yield (Fageria et al, 2010; Fageria et al, 2011). Additionally, it is responsible for the growth of the plant leaf area, increasing the efficiency of solar radiation interception, the photosynthetic rate and, consequently, grain yield (Fageria \& Baligar, 2005). The genotypes of irrigated rice differ in their efficiency of nitrogen use (NUE) (Fageria \& Baligar, 2005; Fageria, 2007, Fageria et al, 2013) and grain yield efficiency index (GYEI) (Fageria \& Santos, 2014). Therefore, appropriate nitrogen management increases NUE and can also improve grain yield (Fageria et al., 2013). Although nitrogen fertilization might compensate the plant's needs when it is not sufficiently available in the soil, the plant response varies according to soil, climate, plant and agronomic efficiency of N (Scivittaro \& Machado, 2004). Nitrogen deficiency is one of the most limiting factors for irrigated rice yield and it differs according to cultivars (Fageria et al, 2007; Fageria et al, 2009). It is often observed (Fageria \& Stone, 2003) due to losses by volatilization, leaching, denitrification and erosion (Fageria \& Baligar, 2005), low application rates and decreased organic matter as a result of successive cultivations. Nitrogen is the most accumulated element after potassium, it composes chlorophyll and influences plant physiology, increasing productivity components, such as the number of panicles per area and the number of grains per panicle, which reflects on rice grain yield and protein content (Fageria et al. 2003; Lin et al., 2009).

In addition to intrinsic plant factors and edaphoclimatic conditions of the cultivation region, crop management interferes with dry matter, solar radiation interception, photoassimilates accumulation, and consequently, grain yield (Argenta et al. 2003). In this sense, the integrated management of the irrigated rice crop, including the use of continuous flooding and fertilization performed at appropriate periods, is important to maximize the efficiency of natural resources and inputs, increase grain yield, reduce production costs and minimize environmental degradation.

This study aimed to determine the influence of periods of initial flooding and nitrogen topdressing on the agronomic performance of 'BRS Jaçanã' and 'Epagri 109' irrigated rice in tropical lowland.

\section{MATERIALAND METHODS}

Two experiments were conducted in a Dystrophic Haplic Gleysol (Santos et al., 2013) floodplain, for two consecutive crop years: 2007/08 and 2008/09. The experimental field in the Palmital Farm, belonging to Embrapa Rice and Beans is located in the city of Goianira GO, $16^{\circ} 26^{\prime} 20^{\prime \prime S}, 49^{\circ} 23^{\prime} 45^{\prime \prime} \mathrm{W}$, altitude of $728 \mathrm{~m}$. Experiments used rice cultivars BRS Jaçanã and Epagri 109. Chemical analysis, granulometric composition and textural classification of the soil were collected at the beginning of the experiment, in the layer $0-0.10 \mathrm{~m}$ depth. The results showed water pH $5.0(1: 2.5) ; 4.2 \mathrm{cmol} \mathrm{dm}^{-3}$ of $\mathrm{Ca}^{2+} ; 1.1$ $\mathrm{cmol}_{\mathrm{c}} \mathrm{dm}^{-3}$ of $\mathrm{Mg}^{2+} ; 77.4 \mathrm{mg} \mathrm{dm}^{-3}$ of $\mathrm{P} ; 55 \mathrm{mg} \mathrm{dm}^{-3}$ of K $\mathrm{K}^{+} ; 3.5$ $\mathrm{mg} \mathrm{dm}{ }^{-1}$ of $\mathrm{Cu} ; 4.2 \mathrm{mg} \mathrm{dm}^{-3}$ of $\mathrm{Zn} ; 385 \mathrm{mg} \mathrm{dm}^{-3}$ of Fe; $31 \mathrm{mg}$ $\mathrm{dm}^{-3}$ of Mn; $27 \mathrm{~g} \mathrm{~kg}^{-1}$ of MO; $323 \mathrm{~g} \mathrm{~kg}^{-1}$ of clay; $240 \mathrm{~g} \mathrm{~kg}^{-1}$ of silt; $437 \mathrm{~g} \mathrm{~kg}^{-1}$ of sand, loam clay soil.

The study evaluated the effects of four different early flooding timings combined with four different $\mathrm{N}$ $\left(90 \mathrm{~kg} \mathrm{ha}^{-1}\right)$ topdressing application in the form of urea. The application timings of the two factors were: 15, 30, 45 and 60 days after seedling emergence (DAE), corresponding to vegetative growth stages V3 - V4; V6 V7; V9 - V10 and V12 - V13, defined by the scale of Counce et al. (2000). A split plot completely randomized experimental design was used according to the methodology by Chacin Lugo (1997), with six replications. The $600 \mathrm{~m}^{2}$ plots were established according to the initial flooding timings, and the $150 \mathrm{~m}^{2}$ subplots, were defined according to $\mathrm{N}$ application timings (N-P-K).

A total of $400 \mathrm{~kg} \mathrm{ha}^{-1}$ of the formula 4-30-16 (N-P-K) was applied at sowing, which was performed in the row system on dry soil, using 80 seeds per meter, spaced 0.17 $\mathrm{m}$ apart. Weed competition was prevented with the application of the pre-emergence herbicide oxadiazon $(0.8$ $\mathrm{kg}$ a.i. ha ${ }^{-1}$ ). Irrigation suppression occurred in the same period for all treatments; stage R8 - R9 - full grain maturity. 
During irrigation, the water depth was uniformly maintained at $10 \mathrm{~cm}$.

At harvest, plant samples were separated into straw (leaves + sheaths + stems) and grain. After drying, the straw dry matter (DMstraw) and total shoot dry matter (DMshoot) were determined. At the same period, the following parameters were recorded: number of tillers and panicles per square meter, plant height, harvest index (HI), number of grains and empty spikelets per panicle, 100grain weight, industrial grain yield, the incidence of sheath blight in stems, and grain yield expressed in $\mathrm{kg} \mathrm{ha}^{-1}$ after moisture adjustment to $13 \%$. In each plot, the number of tillers and panicles were counted in two meters of the planting rows. Plant height was measured from the ground level up to the end of the panicle in ten tillers. Harvest index was obtained by the ratio between the grain production and total dry matter in $1 \mathrm{~m}^{2}$. Ten panicles were collected to determine the number of grains and empty spikelets, and 100-grain weight. The evaluation of spikelet fertility was expressed in grain percentage and it was obtained by the ratio between the number of grains per panicle and the total number of spikelets. To determine the industrial quality of grain, the grain samples were dried to $13 \%$ moisture and stored for 30 days. Following, $100 \mathrm{~g}$ samples of grains were processed using a Suzuki test mill and then the whole grain and broken grain mass was determined. Sheath blight incidence was calculated as a percentage of infected stems in samples of 50 stems per plot. Data were submitted to variance analysis and regression analysis if significant $(p<0.05)$. Grain yield was assessed in joint analysis. Statistical analysis was performed using SISVAR software (Ferreira, 2007).

\section{RESULTS AND DISCUSSION}

The joint variance analysis of grain yield showed a significant effect of crop year. Thus, it is necessary to discuss each year separately. The interaction between initial flooding timings, $\mathrm{N}$ application timings, and crop year shows that the rice cultivars had different behaviors in each year, which can be attributed to environmental variability. This emphasizes the importance of evaluating the grain yield in various harvests.

Early flooding and $\mathrm{N}$ application timings had different effects on the characteristics of both genotypes (Table 1). In relation to dry matter production and plant height, both cultivars had similar behaviors with linear negative responses to flooding timings and $\mathrm{N}$ application in both experimental years, except for cultivar Epagri 109 in the second crop year, which had an increase in DMshoot with the delay of initial flooding.

Regarding the components of grain production, the 100-grain weight of both genotypes was not significantly influenced by the timings of flooding and $\mathrm{N}$ application.
Yoshida (1981) reported that grain weight is a fairly stable yield component and trait of the cultivar. Fageria et al. (2007) also found that $\mathrm{N}$ rates had no effect on grain weight of rice genotypes. However, the correlation between grain weight and grain yield was positive, but not significant, demonstrating that it is not a major factor in the yield of rice crop. The number of panicles per area of the cultivar Epagri 109 was affected by nitrogen fertilizer application timing only in the first year, and there was a linear reduction with the delay of $\mathrm{N}$ application. Camargo et al. (2008) reported that $\mathrm{N}$ application prior to booting increases the number of panicles. The flooding period had a quadratic effect on tiller fertility for cultivar Epagri 109 in the first year, with a maximum of $98 \%$ estimated with initial flooding at 48 DAE, after effective tillering. That is, the number of fertile tillers increased with the delayed onset of soil submersion until that stage. In the second year, the percentage of fertile tillers was similar for both genotypes, presenting linear reduction according to the delay in $\mathrm{N}$ application. In the study carried out by Méndez Larrosa et al. (2001), N application in drained soil at V4 growth stage and followed by flooding provided greater tillering when compared to $\mathrm{N}$ application on the water layer. However, these authors found no effects of water and $\mathrm{N}$ management on the yield of rice.

For cultivar BRS Jaçanã, the number of grains per panicle reduced with $\mathrm{N}$ application timings, while cultivar Epagri 109 increased number of grains per panicle with flooding timings in the second year. This 'Epagri 109' response is different from the results obtained by Gomes et al. (2007), who found a linear reduction in the number of spikelets per panicle of 'BRS Querência' when irrigation was delayed from V3 to V9. Cultivar Epagri 109 showed a quadratic response in the second year for spikelet fertility, with a maximum of $87 \%$, estimated with $\mathrm{N}$ fertilization at 33 DAE. Jennings et al. (1979) reported that normal spikelet sterility must be situated between $10 \%$ and $15 \%$ to obtain high yields. On the other hand, Yoshida (1981) found that even under favorable environmental conditions, $15 \%$ spikelet sterility was considered normal in rice. Fageria $e t$ al. (2007) reported that spikelet sterility in irrigated rice is a genotypic trait and can be reduced with proper management of N. However, Méndez Larrosa et al. (2009) evaluated the effects of $\mathrm{N}$ management on the susceptibility of the rice plant at low temperatures in the reproductive stage and found that $\mathrm{N}$ rate or application timing did not affect spikelet sterility. The flooding timing and $\mathrm{N}$ application in the two years of experiment did not significantly influence the harvest index and industrial yield of grains for both cultivars.

Initial flooding timing in the first year, had a quadratic effect on the severity of sheath blight during flowering and harvest. In the second year, there was an increased 
severity of sheath blight during flowering for cultivar BRS Jaçanã (Table 1). At flowering and harvest respectively, maximum values of $62 \%$ and $31 \%$ of tillers with sheath blight, were estimated with flooding starting at 24 DAE. The water layer favors disease development, because the sclerotia of Rhizoctonia solani are able to float on water and accumulate around the rice plant, causing an initial infection of the stems in the water. For cultivar Epagri 109 in the first crop year, early flooding had a negative linear effect on the severity of sheath blight during flowering and harvesting. Thus, early flooding timings favors an increased severity of sheath blight in irrigated rice stems. The period of $\mathrm{N}$ application influenced the percentage of tillers affected by sheath blight only in the second year. There was a linear reduction in the severity of the sheath blight during harvesting and flowering of 'BRS Jaçanã' and 'Epagri 109', respectively, with delayed applications of $\mathrm{N}$.

For both crop years, there was an interaction between initial flooding periods and $\mathrm{N}$ application on grain yield for both genotypes. In the first initial flooding period for

Table 1: Regression equations of agronomic traits for rice cultivars BRS Jaçanã and Epagri 109 obtained in relation to initial flood timings and $\mathrm{N}$ application, from 15 to 60 days after emergence (x), for both crop years, and coefficients of determination $\left(\mathrm{R}^{2}\right)$

\begin{tabular}{|c|c|c|c|c|}
\hline Trait & Year & Treatment & Regression Equation & $\mathbf{R}^{2}$ \\
\hline \multicolumn{5}{|c|}{ BRS Jaçanã } \\
\hline \multirow{3}{*}{ DMstraw $\left(\mathrm{g} \mathrm{m}^{-2}\right)$} & $1^{\circ}$ & Water Manegement & $y=876-2.6229 x$ & $0.32 * *$ \\
\hline & & N Manegement & $y=1020-6.4417 x$ & $0.93 * *$ \\
\hline & $2^{\circ}$ & N Manegement & $y=1023-4.9780 x$ & $0.96^{* *}$ \\
\hline \multirow{3}{*}{ DMshoot $\left(\mathrm{g} \mathrm{m}^{-2}\right)$} & $1^{\circ}$ & Water Manegement & $y=1820-5.9044 x$ & $0.39 *$ \\
\hline & & N Manegement & $y=2016-11.1381 x$ & $0.83^{* *}$ \\
\hline & $2^{\circ}$ & N Manegement & $y=1827-8.3227 x$ & $0.95^{* *}$ \\
\hline \multirow{3}{*}{ Plant Height (cm) } & $1^{\circ}$ & Water Manegement & $y=95.3-0.1567 x$ & $0.65 * *$ \\
\hline & & N Manegement & $y=98.8-0.2525 x$ & $0.95^{* *}$ \\
\hline & $2^{\circ}$ & N Manegement & $y=99.5-0.3429 x$ & $0.91 * *$ \\
\hline Fertile Tillers (\%) & $2^{\circ}$ & N Manegement & $y=96-0.0775 x$ & $0.76^{* *}$ \\
\hline Grains $\left(n^{\circ}\right.$ panicles $\left.^{-1}\right)$ & $2^{\circ}$ & N Manegement & $y=104-0.2853 x$ & $0.33 * *$ \\
\hline \multirow{2}{*}{ Tillers with sheath bright, at flowering (\%) } & $1^{\circ}$ & Water Manegement & $y=47.9+1.1208 x-0.0231 x^{2}$ & $0.80 * *$ \\
\hline & $2^{\circ}$ & Water Manegement & $y=15.5+0.4388 x$ & $0.49 * *$ \\
\hline \multirow{2}{*}{ Tillers with sheath blight, at harvest (\%) } & $1^{\circ}$ & Water Manegement & $y=24.0+0,5604 x-0.0115 x^{2}$ & $0.80 *$ \\
\hline & $2^{\circ}$ & N Manegement & $y=53.4-0.3854 x$ & $0.72 * *$ \\
\hline \multicolumn{5}{|c|}{ Epagri 109} \\
\hline \multirow{4}{*}{ DMstraw $\left(\mathrm{g} \mathrm{m}^{-2}\right)$} & $1^{\circ}$ & Water Manegement & $y=1191-11.2795 x$ & $0.95 * *$ \\
\hline & & N Manegement & $y=994-6.0116 x$ & $0.85^{* *}$ \\
\hline & $2^{\circ}$ & Water Manegement & $y=767-5.3310 x$ & $0.95^{* *}$ \\
\hline & & N Manegement & $y=1115-3.9748 x$ & $0.78^{* *}$ \\
\hline \multirow{4}{*}{ DMshoot $\left(\mathrm{g} \mathrm{m}^{-2}\right)$} & $1^{\circ}$ & Water Manegement & $y=2196-18.8167 x$ & $0.99 * *$ \\
\hline & & N Manegement & $y=1868-10.0656 x$ & $0.91 * *$ \\
\hline & $2^{\circ}$ & Water Manegement & $y=1462+7.3158 x$ & $0.90^{* *}$ \\
\hline & & N Manegement & $y=1981-6.5445 x$ & $0.82 * *$ \\
\hline \multirow{3}{*}{ Plant Height (cm) } & $1^{\circ}$ & Water Manegement & $y=89-0.2088 x$ & $0.79 * *$ \\
\hline & & N Manegement & $y=85-0.0846 x$ & $0.80 * *$ \\
\hline & $2^{\circ}$ & N Manegement & $y=97-0.1917 x$ & $0.74 * *$ \\
\hline Panicle $\left(\mathrm{n}^{\mathrm{o}} \mathrm{m}^{-2}\right)$ & $1^{\circ}$ & N Manegement & $y=631-1.7925 x$ & $0.90 *$ \\
\hline \multirow{2}{*}{ Fertile Tillers (\%) } & $1^{\circ}$ & Water Manegement & $y=87+0.4315 x-0.0045 x^{2}$ & $0.99 * *$ \\
\hline & $2^{\circ}$ & N Manegement & $y=94-0.1958 x$ & $0.76^{* *}$ \\
\hline Grains $\left(\mathrm{n}^{\circ}\right.$ panicle $\left.{ }^{-1}\right)$ & $2^{\circ}$ & Water Manegement & $y=72+0.3428 x$ & $0.98 * *$ \\
\hline Spikelet Fertility (\%) & $2^{\circ}$ & N Manegement & $y=77+0.6097 x-0.0092 x^{2}$ & $0.92 * *$ \\
\hline \multirow{2}{*}{ Tillers with sheath blight, at flowering (\%) } & $1^{\circ}$ & Water Manegement & $y=95-1.1992 x$ & $0.69 * *$ \\
\hline & $2^{\circ}$ & N Manegement & $y=23.3-0.2396 x$ & $0.97 *$ \\
\hline Tillers with sheath blight, at harvest (\%) & $1^{\circ}$ & Water Manegement & $y=47.5-0.5996 x$ & $0.69 * *$ \\
\hline
\end{tabular}

$*$ and $* *$ Significant at $5 \%$ and $1 \%$ probability, respectively. 
BRS Jaçanã there was a linear reduction of grain yield in relation to the delay in $\mathrm{N}$ application, with a reduction of $63 \mathrm{~kg} \mathrm{ha}^{-1}$ of grains per each day of delay (Figure 1A). In the second year, there was a quadratic response, with maximum of $7418 \mathrm{~kg} \mathrm{ha}^{-1}$ estimated with fertilization at 23 DAE (Figure 1B). In the delayed flooding, for both years, this cultivar had a quadratic response, with maximum estimated values of 7917 and $6989 \mathrm{~kg} \mathrm{ha}^{-1}$ with $\mathrm{N}$ application at 32 and 36 DAE in the first (Figure 1A) and second year (Figure 1B), respectively. Santos et al. (1999) evaluated different water management forms in rice cultivation in tropical lowland found and increased yield and improved industrial grain quality with the use of continuous flooding throughout the cycle, compared to the intermittent flooding in the vegetative stage and followed by continuous flooding in the reproductive and maturation stages.

There was a linear decrease in the grain yield of BRS Jaçanã with early nitrogen application and delayed flooding in the second year. For both experimental years, grain yield showed a quadratic response when $\mathrm{N}$ was applied in delay, with maximum values of 6652 and 6815 $\mathrm{kg} \mathrm{ha}^{-1}$ estimated with flooding initiated at 34 (Figure 1A) and 43 DAE (Figure 1B). Flooding initiated at 30 DAE produced linear decrease of grain yield with delayed $\mathrm{N}$ applications, in the second year.

In the first timing of $\mathrm{N}$ application, grain yield for cultivar Epagri 109 linearly declined as flooding was delayed in the first year, with a reduction of $27 \mathrm{~kg} \mathrm{ha}^{-1}$ of grains per each day of delay (Figure 2A). In delayed fertilization, the reduction of grain yield for this cultivar was higher with delayed initial flooding in the first year, with a reduction of $89 \mathrm{~kg} \mathrm{ha}^{-1}$ of grains per day of delay (Figure 2A), showing a quadratic response in the second year, with the maximum of $7460 \mathrm{~kg} \mathrm{ha}^{-1}$ estimated with flooding at 43 DAE (Figure 2B).

In earlier flooding, the grain yield of cultivar Epagri 109 showed a quadratic response in the second year, with maximum value of $7724 \mathrm{~kg} \mathrm{ha}^{-1}$ estimated with fertilization performed at $33 \mathrm{DAE}$ (Figure 2B). Similarly to cultivar BRS
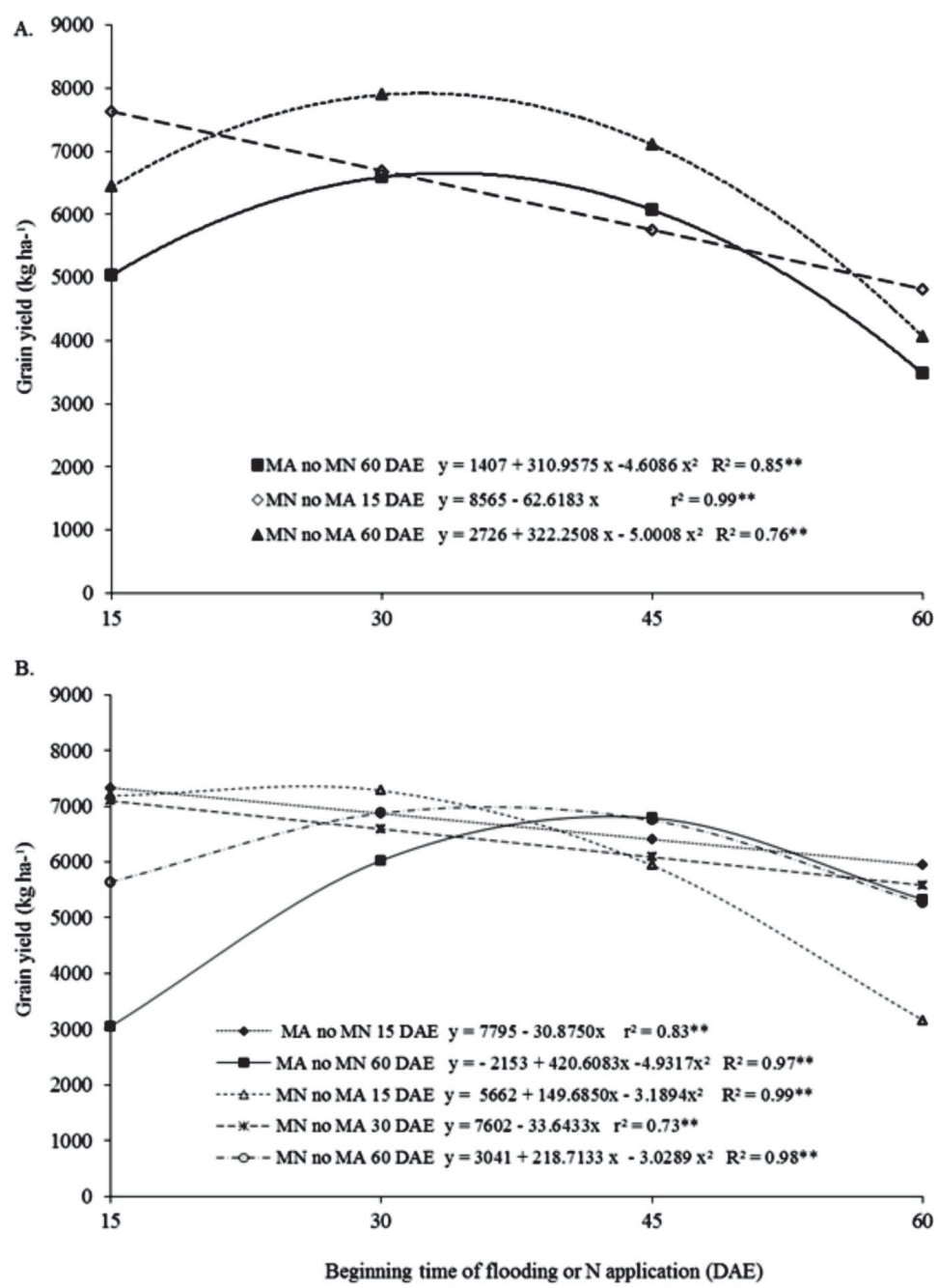

Figure 1: Effects of the interaction between initial flooding timing and $\mathrm{N}$ application on grain yield of rice cultivar BRS Jaçanã irrigated in the first (A.) and second (B) year. MA: initial flood timing, MN: N application timings; DAE: days after emergence. 
Jaçanã with delayed flooding in both years, cultivar Epagri 109 showed a quadratic response and maximum values estimated between 7416 and $8124 \mathrm{~kg} \mathrm{ha}^{-1}$ at 30 and 35 DAE in the first (Figure 2A) and second years (Figure 2B), respectively. Scivittaro et al. (2010) reported a reduction in yield of irrigated rice with increased time between $\mathrm{N}$ application (in the form of urea) and soil submersion from five to ten days. Nitrogen losses by ammonia volatilization derived from the use of urea were determined by these authors in a range between $15 \%$, in saturated soil, and $22 \%$ in moist soil, when the interval was ten days. Delay in the irrigation time beyond the initial tillering reduces the absorption of macro and micronutrients by rice (Scivittaro et al., 2011). The combination of $\mathrm{N}$ application times and initial irrigation by flooding affects the phytotoxicity of herbicides of the imidazolinone group in tolerant rice plants. Ávila et al. (2009) found lower phytotoxicity when nitrogen fertilization was carried out until the fifth day after herbicide application and early irrigation.
The current recommendation of nitrogen fertilization in the South of Brazil (SOSBAI, 2012) suggests that, for rice grown in dry soil seeding systems, the first $\mathrm{N}$ application in early tillering should precede the application of water in the crop. By doing so, water from irrigation is able to incorporate $\mathrm{N}$ into the soil, minimizing the loss of ammonia from urea. According to Scivittaro et al. (2010), the use of urea treated with urease inhibitor can temporarily inhibit the enzymatic degradation of urea, allowing its application up to ten days before the beginning of irrigation, with no damage to grain yield and $\mathrm{N}$ accumulation on rice. It is possible that in this study, the greatest responses of cultivars in relation to timings of earlier flooding and $\mathrm{N}$ application are also due to lower losses of the nutrient.

The decrease in grain yield in both cultivars with the delay of nitrogen fertilization is possibly due to a reduced percentage of fertile tillers and number of panicles per area, since this component is more closely correlated with rice yield (Fageria et al., 2007). Grain yield and its components have been shown highly dependent on the

A.
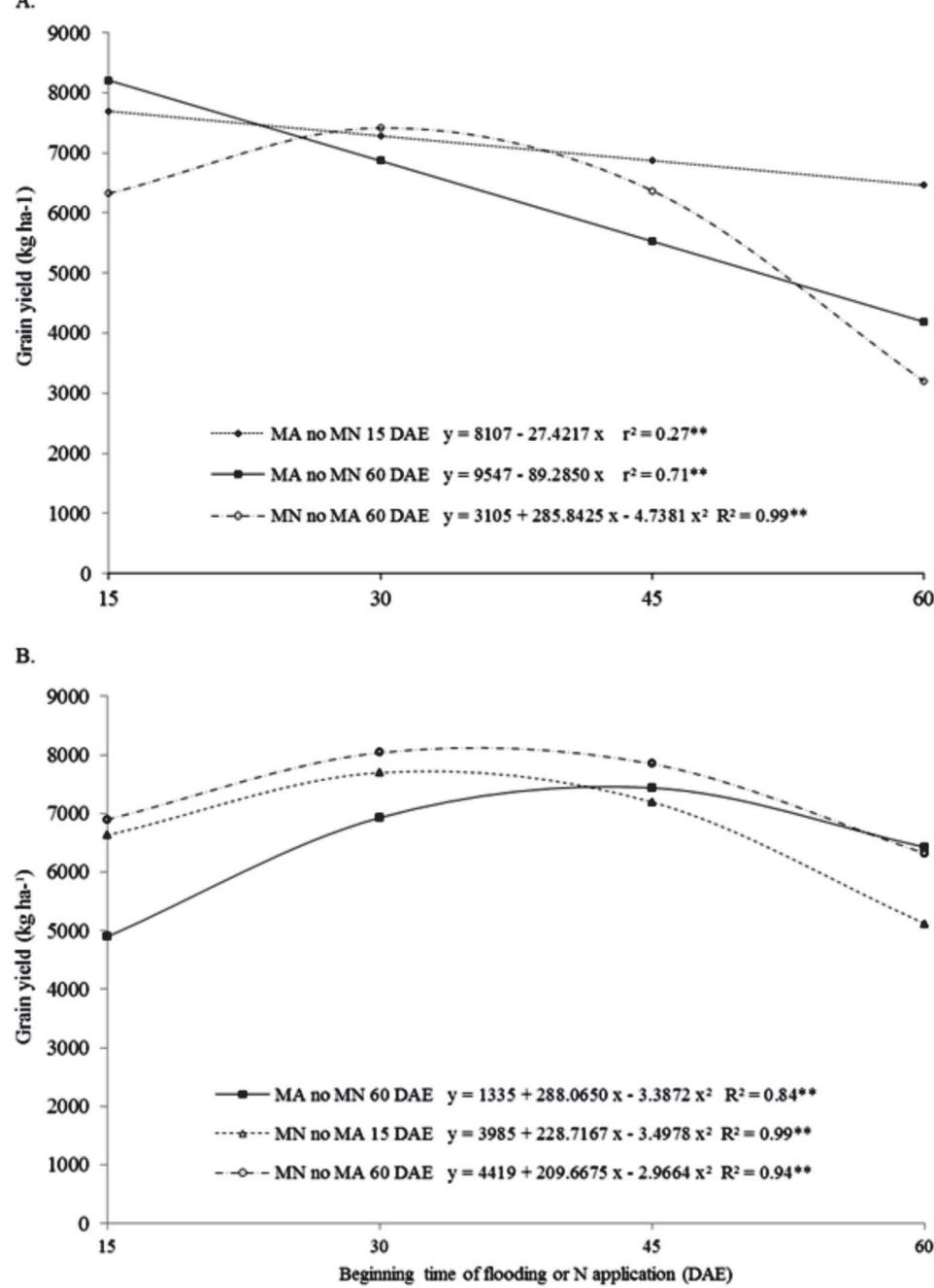

Figura 2: Effects of the interaction between initial flood timing and $\mathrm{N}$ application on grain yield of rice cultivar Epagri 109 irrigated in the first (A.) and second (B) year. MA: initial flood timing, MN: N application timings; DAE: days after emergence. 


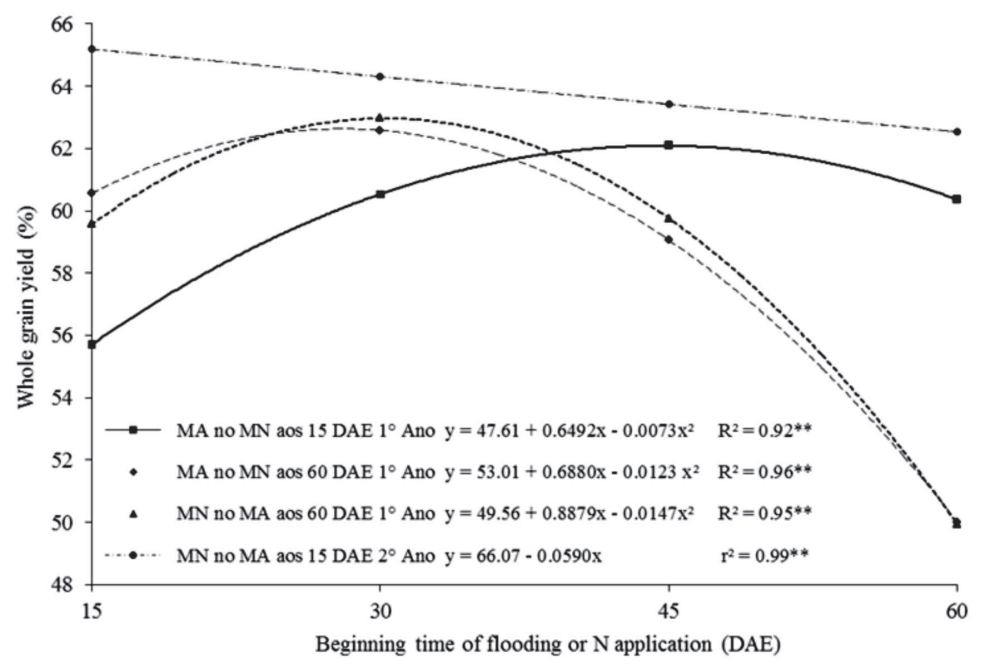

Figura 3: Effects of the interaction between initial flood timing and $\mathrm{N}$ application on whole grain yield of rice cultivar BRS Jaçanã irrigated in the first and second year. MA: initial flood timing, MN: N application timings; DAE: days after emergence.

period of soil submersion (Gomes et al., 2007, Ramírez et al., 2007). In assessing the performance of the early cultivar BRS Querência in relation to initial irrigation, Gomes et al. (2007) concluded that delayed soil submersion from $15 \mathrm{DAE}$, reduces the number of spikelets per panicle, increases sterility and promotes reduction in grain yield. Likewise, Ramírez et al. (2007) verified a yield reduction of cultivar Irga 424 of irrigated rice of $1000 \mathrm{~kg} \mathrm{ha}^{-1}$ per each ten days of delay in the beginning of irrigation.

The commercial value of rice is determined by its industrial grain yield, which is obtained by the ratio between the amount of whole grains and broken grains. In both years, there was an interaction between initial flooding and $\mathrm{N}$ application on whole grain yield of BRS Jaçanã. In the first and last period of $\mathrm{N}$ application, whole grain yield showed a quadratic response in the first year, with maximum values of $62 \%$ and $63 \%$ estimated with initial flooding at 45 and 28 DAE, respectively (Figure 3). At the latest time of initial flooding in the first year, whole grain yield also presented a quadratic response, with the highest value estimated at $63 \%$ with $\mathrm{N}$ application at $30 \mathrm{DAE}$. In the second year, there was a linear decrease in the yield of whole grains of BRS Jaçanã at the first flood timing and delayed $\mathrm{N}$ fertilization. That is, flooding and $\mathrm{N}$ topdressing application at the beginning of tillering produced grains with higher resistance to breakage during processing, which is an important characteristic for rice commercialization. Management practices, involving nitrogen fertilization in irrigated rice are directly related to qualities and defects of grain. Several studies suggest that the industrial grain yield is more influenced by genotypes and environmental conditions and that the effects of $\mathrm{N}$ application are not persistent (Freitas et al., 2001; Freitas et al., 2007, Silva et al. 2013).

In the present study, when flooding was initiated earlier, the fertilization with nitrogen in BRS Jaçanã should also be carried out earlier, up to $23 \mathrm{DAE}$, after the beginning of tillering, resulting in higher productivity and yield of whole grain. In 'Epagri 109', which has lower initial growth, it should be applied until 33 DAE or mid-tillering. When soil submergence is carried out later, $\mathrm{N}$ should be applied between 30 to $35 \mathrm{DAE}$, as there may be further $\mathrm{N}$ loss if nitrogen fertilization is performed without the presence of the water layer. In the early application of $\mathrm{N}$, flooding should also be initiated early, once the delay in soil submersion reduces grain yield, probably due to the loss of $\mathrm{N}$. When nitrogen fertilization is applied later, flooding may be initiated later, up to $43 \mathrm{DAE}$, corresponding to stages $\mathrm{V} 9-\mathrm{V} 10$, that is, at the end of active tillering.

\section{CONCLUSIONS}

The delay in continuous flooding and topdressing $\mathrm{N}$ application reduces grain biomass, quality, and yield of rice.

In cultivars with higher initial growth, such as BRS Jaçanã, flooding should be carried out at the beginning of tillering, whereas for cultivars with slower initial growth, such as Epagri 109, the water layer may be established until mid-tillering.

Early flooding enhances sheath blight severity in rice stems.

For a higher productive potential of irrigated rice and better grain quality, it is necessary to associate early flooding and efficient control of sheath blight.

\section{AKNOWLEDGEMENTS}

The authors thank the National Council for Technological and Scientific Development (CNPq) for financial support and for the awarded Productivity Fellowships. 


\section{REFERENCES}

Argenta G, Sangoi L, Silva PRF da, Rampazzo C, Gracietti LC, Strieder ML, Forsthofer EL \& Suhre E (2003) Potencial de rendimento de grãos de milho em dois ambientes e cinco sistemas de produção. Scientia Agraria, 4:27-34

Ávila LA de, Cezimbra DM, Marchesan E, Machado SL de O, Pasini M, Glier C \& Ferreira RB (2009) Época de aplicação de nitrogênio e de início da irrigação na fitotoxidade causada pela aplicação de imidazolinonas em arroz tolerante. Ciência Rural, 39:1647-1652.

Camargo ER, Marchesan E, Rossato TL, Teló GM \& Arosemena DR (2008) Influência da aplicação de nitrogênio e fungicida no estádio de emborrachamento sobre o desempenho agronômico do arroz irrigado. Bragantia, 67:153-159.

Chacin Lugo F (1997) Cursos avances recientes en el diseño y analisis de experimentos. Caracas, Universidad Central de Venezuela. 145p

Counce PA, Keisling TC \& Mitchell AJA (2000) Uniform, objective, and adaptative system for expressing rice development. Crop Science, 40:436-443.

Fageria NK \& Baligar VC (2005) Enhancing nitrogen use efficiency in crop plants. Advances in Agronomy, 88:97-185.

Fageria NK \& Santos AB dos (2014) Lowland rice genotypes evaluation for nitrogen use efficiency. Journal of Plant Nutrition, $37: 1410-1423$.

Fageria NK \& Stone LF (2003) Manejo do nitrogênio. In: Fageria NK, Stone LF \& Santos AB dos (Eds.) Manejo da fertilidade do solo para o arroz irrigado. Santo Antônio de Goiás, Embrapa Arroz e Feijão. p.51-94.

Fageria NK (2007) Yield physiology of rice. Journal of Plant Nutrition, 30:843-879.

Fageria NK, Baligar VC \& Jones CA (2011) Growth and mineral nutrition of field crops. $3^{\mathrm{a}}$ ed. Boca Raton, CRC Press. 560p.

Fageria NK, Morais OP de \& Santos AB dos (2010) Nitrogen use efficiency in upland rice genotypes. Journal of Plant Nutrition, 33:1696-1711.

Fageria NK, Santos AB dos \& Cutrim V dos A (2007) Produtividade de arroz irrigado e eficiência de uso do nitrogênio influenciadas pela fertilização nitrogenada. Pesquisa Agropecuária Brasileira, 42:1029-1034.

Fageria NK, Santos AB dos \& Cutrim V dos A (2008) Dry matter and yield of lowland rice genotypes as influence by nitrogen fertilization. Journal of Plant Nutrition, 31:788-795.

Fageria NK, Santos AB dos \& Cutrim V dos A (2009) Nitrogen uptake and its association with grain yield in lowland rice genotypes. Journal of Plant Nutrition, 2:1965-1974.

Fageria NK, Santos AB dos \& Oliveira JP (2013) Nitrogen-use efficiency in lowland rice genotypes under field conditions. Communications in Soil Science and Plant Analysis, 44:24972506 .

Fageria NK, Slaton NA \& Baligar VC (2003) Nutrient management for improving lowland rice productivity and sustainability. Advances in Agronomy 80:63-152.

Ferreira DF (2007) Sistema de análises de variância para dados balanceados - SISVAR: programa de análises estatísticas e planejamento de experimentos. Versão 5.1. Lavras, UFLA

Freitas JG de, Cantarella H, Salomon MV, Malavolta VMA, Castro LHSM de, Gallo PB \& Azzini LE (2007) Produtividade de cultivares de arroz irrigado resultante da aplicação de doses de nitrogênio. Bragantia, 66:317-325.
Freitas JG de, Azzini LE, Cantarella H, Bastos CR, Castro LHSM de, Gallo PB \& Felício JC (2001) Resposta de cultivares de arroz irrigado ao nitrogênio. Scientia Agricola, 58:573-579.

Gomes A da S, Gomes DN, Ferreira LHG, Scivittaro WB, Pereira RSD, Winkler AS \& Chiarelo C (2007) Desempenho do arroz irrigado, cultivar BRS Querência, em função do início da irrigação e do tratamento de sementes com fungicida de dupla ação. In: $5^{\circ}$ Congresso Brasileiro de Arroz Irrigado / $27^{a}$ Reunião da Cultura de Arroz Irrigado, Pelotas. Anais, Embrapa Clima Temperado. p.426-430.

Jennings PR, Coffmann WR \& Kauffmann HE (1979) Rice improvement. Los Baños, International Rice Research Institute. $186 \mathrm{p}$.

Lin XQ, Zhu DF, Chen HZ \& Zang YP (2009) Effect of plant density and nitrogen fertilizer rates on grain yield and nitrogen uptake of super hybrid rice (Oryza sativa L.) Journal of Agricultural Biotechnology and Sustainable Development, 1:4453.

Méndez Larrosa RF, Marchezan E, Aita C \& Coradini JZ (2001) Eficiência da aplicação de nitrogênio no perfilhamento do arroz em três manejos de irrigação. Ciência Rural, 31:745-749.

Méndez Larrosa RF, Marchezan E, Silva LS da \& Ávila LA de (2009) Doses e épocas de aplicação de nitrogênio na suscetibilidade do arroz à temperatura baixa na fase reprodutiva. Ciência Rural, 39:992-997.

Ramírez HV, Herzog RL da S, Chaves A da C \& Menezes VG (2007) Aumento da produtividade através do manejo da água de irrigação na cultura do arroz irrigado. In: $5^{\circ}$ Congresso Brasileiro de Arroz Irrigado / $27^{\mathrm{a}}$ Reunião da Cultura de Arroz Irrigado, Pelotas. Anais, Embrapa Clima Temperado. p.434-435.

Santos AB dos, Fageria NK, Stone LF \& Santos C (1999) Manejo de água e de fertilizante potássico na cultura de arroz irrigado. Pesquisa Agropecuária Brasileira, 34:565-573.

Santos HG dos, Almeida JÁ, Oliveira JB de, Lumbreras JF, Anjos LHC dos, Coelho MR, Jacomine PKT, Cunha TJF \& Oliveira VA de (2013) Sistema Brasileiro de Classificação de Solos. $3^{\mathrm{a}}$ ed. Brasília, Embrapa. 353p.

Scivittaro WB \& Machado MO (2004) Adubação e calagem para a cultura do arroz irrigado. In: Gomes A da S \& Magalhães Junior AM de (Eds.) Arroz irrigado no Sul do Brasil. Brasília, Embrapa Informação Tecnológica. p.259-303.

Scivittaro WB, Gonçalves DRN, Braun JAF \& Castilhos RMV (2011) Absorção de nutrientes pelo arroz em resposta à época de início de irrigação. Pelotas, Embrapa Clima Temperado. 27p. (Boletim de Pesquisa e Desenvolvimento, 138).

Scivittaro WB, Gonçalves DRN, Vale MLC \& Ricordi VG (2010) Perdas de nitrogênio por volatilização de amônia e resposta do arroz irrigado à aplicação de ureia tratada com o inibidor de urease NBPT. Ciência Rural, 40:1283-1289.

Silva LP da, Alves BM, Silva LS da, Pocojeski E, Kaminski TA \& Roberto BS (2013) Adubação nitrogenada sobre rendimento industrial e composição dos grãos de arroz irrigado. Ciência Rural, 43:1128-1133.

SOSBAI - Sociedade Sul-Brasileira de Arroz Irrigado (2012) Arroz irrigado: recomendações técnicas da pesquisa para o Sul do Brasil. Itajaí, SOSBAI. 179p.

Stone LF (2005) Eficiência do uso da água na cultura do arroz irrigado. Santo Antônio de Goiás, Embrapa Arroz e Feijão. 48p. (Documentos, 176).

Yoshida S (1981) Fundamentals of rice crop Science. Los Baños, International Rice Research Institute. 269p. 